\title{
ОПТИМІЗАЦІЯ СТРУКТУРИ ТА УПРАВЛІННЯ САНАТОРНО-КУРОРТНОЮ УСТАНОВОЮ
}

\author{
О. Ю. Азархов \\ Пу "Санаторій "Металург"

\begin{abstract}
В статті розглянуті особливості організаціїта управління санаторно-курортною установою. Визначені інформаційні
\end{abstract} \\ потоки та необхідне інформаційне забезпечення процесу управління. Запропонована оптимізована структура са- \\ наторно- курортної установи.
}

Ключові слова: санаторно-курортна установа, організаційна структура, управління, інформаційні потоки, медична інформаційна система.

\section{ОПТИМИЗАЦИЯ СТРУКТУРЫ И УПРАВЛЕНИЯ САНАТОРНО-КУРОРТНЫМ УЧРЕЖДЕНИЕМ}

\section{4 "Санаторий «Метамург”"}

А. Ю. Азархов

В статье рассмотрены особенности организации и управления санаторно-курортным учреждением. Определены информационные потоки и необходимое информационное обеспечение процесса управления. Предложена оптимизированная структура санаторно- курортного учреждения.

Ключевые слова: санаторно-курортное учреждение, организационная структура, управление, информационные потоки, медицинская информационная система.

\section{OPTIMIZATION OF STRUCTURE AND MANAGEMENT IN SANATORIUMS}

O.Yu. Azarkhov

\section{Private sanatorium "Metalurh"}

\begin{abstract}
The article describes the features ot organization and management of sanatoriums. Informational flows that are necessary to ensure control process are defined. Optimized structure of health resort facility proposed.
\end{abstract}

Key words: sanatorium establishment, organizational structure, management, information flows, medical information system.

Вступ. Розв'язання проблеми управління лікувальним процесом санаторно-курортних установ відрізняється від підходів, що застосовуються при вирішенні цього завдання в охороні здоров'я, зокрема в лікарнях і поліклініках. 3 одного боку, більш чітко виражена спеціалізація санаторіїв, ніж лікарень, з іншого - санаторій є відкритою системою, що активно взаємодіє із зовнішнім середовищем, а лікарня - закритою, що іноді майже повністю виключає можливість такої взаємодії. В санаторії хворий перебуває фіксоване число днів, у лікарні змінне. Нарешті, відрізняються самі принципи лікування: в санаторії лікування проводять грунтуючись в основному на використанні природно-курортних факторів, а в охороні здоров'я - на терапевтичних або хірургічних мето- дах лікування [1]. В зв'язку з цим організація управління санаторно-курортним закладом вимагає оптимізації з урахуванням всіх його особливостей і специфіки.

Метою даної роботи $є$ виділення особливостей та оптимізація організаційної структури та процесу управління санаторно-курортним закладом для досягнення максимального терапевтичного або профілактичного ефекту та економічної ефективності.

Результати та їх обговорення. Медичні інформаційні системи (MIC) для управління санаторнокурортними установами суттєво відрізняються від MIC, що розробляються в лікувально-профілактичних закладах. В санаторіях хворого лікують в фазі ремісії або на тлі згасання активного процесу, в лікарні

(C) О. Ю. Азархов 
таких хворих виписують на поліклінічне лікування або на роботу і лише через кілька місяців направляють на повторне обстеження або санаторно-курортне лікування.

Особливості санаторно -курортних МIC відображені на рисунку 1.
Розглянемо функціональне призначення вузлів і блоків оперативно-диспетчерського контуру управління реабілітаційно-відновлювальним лікуванням [2, 3].

Блок реєстратури призначений для забезпечення поселення; складання комп'ютерного анамнезу за допомогою автоінтерв'юера; заповнення індивідуаль-

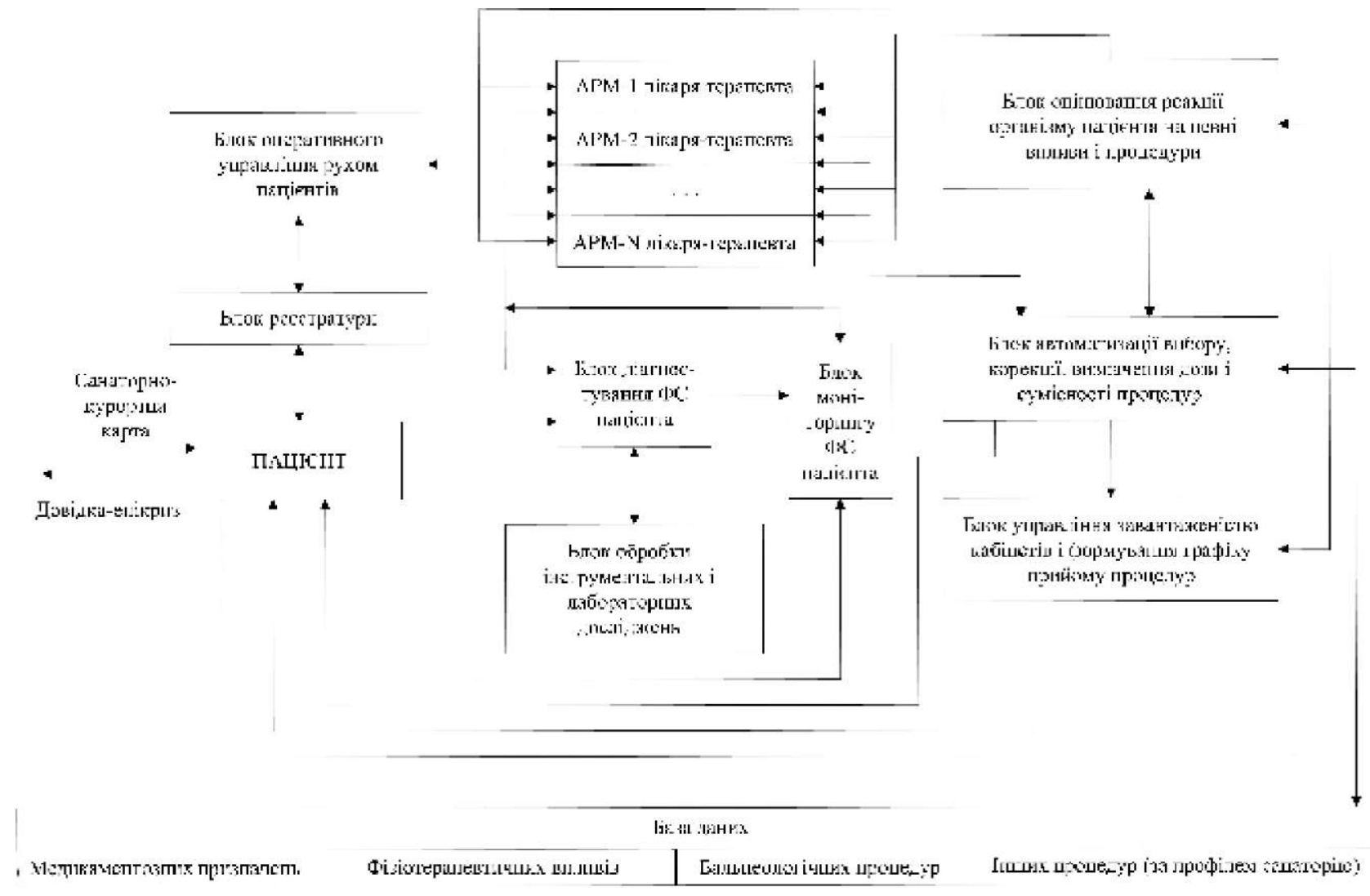

Puc. 1. Структурна схема оперативно-диспетчерського контуру управління реабілітаційно-відновлювальним лікуванням.

ноі картки пацієнта, проведення психологічного тестування (за необхідності); видача пацієнту індивідуальної електронної пластикової картки; встановлення первинного діагнозу, забезпечення діалогу за допомогою типового комплексу для автоматизованого опитування пацієнтів; повна автоматизація введення формалізованих запитів від пацієнтів; автоматичний облік зайнятості кожного ліжка санаторного закладу; виведення візуальної інформації про вільні та зайняті місця у кожному корпусі головному лікарю, лікареві, медсестрі приймального відділення, зазначення статі пацієнтів, типу їх вищої нервової діяльності і рис особистості для оцінки сумісності пацієнтів, що поселяються разом.

Блок оперативного управління рухом пацієнтів дозволяє проводити розподіл пацієнтів до лікарів-терапевтів; корегування і контроль розподілу прийому процедур.
Блок діагностування функиіонального стану пацієнтів $i$ блок обробки інструментальних $i$ лабораторних досліджень забезпечує проведення функціональної діагностики (ЕКГ, ФПГ, ЕМГ, ФЗД, стабілоплатформа, УЗД, тепловізійна діагностика, рентгенографічне або томографічне дослідження); лабораторної діагностики; психологічної діагностики, діагностику методами нетрадиційної медицини (за Фолем, Ріодораком, Накатані тощо); проведення масових досліджень функцій і систем організму хворого, проведення функціональних проб; розрахунок показників для визначення функціональних резервів.

Автоматизоване робоче місце лікаря-терапевта надає можливість формулювання лікувальних призначень; автоматизованого вибору, корегування, визначення дози і параметрів процедур та інших терапевтичних впливів з урахуванням їх сумісності; встановлення інструментального діагнозу; оцінювання реакції 
організму пацієнтів на певні дії і процедури; оцінювання поточного функціонального стану пацієнта; загальний супровід закріплених пацієнтів; розробка і вибір лікарських методик з урахуванням використання спеціалізованих пристроїв для визначення прихованої патології при експрес-аналізі стану хворого в день приїзду; розробка набору ознак (номенклатур ознак) з урахуванням використання спеціалізованих пристроїв для: а) визначення функціональних резервів і прихованої патології при експрес-аналізі стану хворого в день приїзду і початку лікування; б) оцінки і контролю стану хворого під час прийому процедур; в) визначення стану хворого в динаміці лікування; г) визначення ефективності лікування, прогнозу і рекомендацій.

Блок періодичного або, за необхідності, постійного моніторингу функціонального стану пацієнтів відстежує основні показники життєдіяльності організму пацієнта з урахуванням усіх призначених впливів i процедур; забезпечує проведення досліджень 3 визначення інформативності різних фізіологічних параметрів; забезпечує збір і попередню обробку медичної інформації при автоматизованому стеженні за станом функцій і систем організму хворого; генерує сигнали тривоги при виході значень біомедичних сигналів за встановлені норми; аналіз отриманих показників і видача лікарського висновку для встановлення та уточнення його прогнозу і лікування.

База даних медикаментозних призначень, фізіотерапевтичних впливів, бальнеологічних процедур включає в себе всі необхідні показання і протипоказання, сумісність з іншими впливами і процедурами, якісні та кількісні параметри впливів і процедур.

Блок управління завантаженістю кабінетів та формування графіку прийому процедур формує для кожного відпочивальника індивідуальний, максимально адаптований під його діагноз і призначення, графік відпускання процедур.

\section{Лтература}

1. Основы курортологии / сост. А. В. Скибицкий, В. И. Скибицкая. - М. : Феникс, 2008. - 560 с.

2. Ладуба Ю. М. Санаторний етап відновлювального лікування хворих на гострі та хронічні неспецифічні захворювання легенів за умов регіонального реабілітаційного відновлення : автореф. дис. на здобуття наук. ступеня канд. мед. наук : спец. 14.01.33 «Курортологія та фізіотерапія» /
}

Блок навчання персоналу санаторію вирішує завдання: ознайомлення користувачів $з$ принципами побудови і функціонування системи та їх навчання методиці роботи; навчання медичного персоналу заповненню та роботі з формалізованими документами, діалогами або підготовкою даних для введення в ЕОМ; навчання методиці встановлення діагнозу i побудови моделі лікування в режимі діалогу з ЕОМ.

Нарешті, блок автоматизації вибору, корегування, визначення дози і сумісності процедур дає можливість проводити автоматичний облік кількості відпущених процедур по кожному хворому, кабінету, відділенню, санаторію; накопичення даних для аналізу, що використовуються для: а) передачі даних про переносимість процедур в кабінет функціональної діагностики та до лікаря; б) обліку кліматопроцедур.

Висновок. Основною особливістю системи медичного обслуговування в санаторно-курортних установах є тісний перетин завдань управління та технології медичного обслуговування, що будуються на використанні курортних факторів. Існуючі інформаційні потоки медичного забезпечення розділені на такі основні групи: збору та обробки інформації про хворих, діагностики, організації лікувального процесу (оперативного управління рухом хворих), медичної статистики та звітності. Ці інформаційні потоки забезпечують вирішення завдань прийому і розміщення хворих, встановлення попереднього діагнозу, маршрутизації хворих по діагностичних і лікувальних кабінетах, організації консультацій вузьких фахівців, проведення лабораторних, інструментальних досліджень та рентгенобстежень, встановлення основного і супутнього діагнозів, формування планів лікування та обстеження, організації лікування, оформлення епікризу та виписки хворого, організації його побуту та культурно-масового обслуговування, формування форм облікової та звітної документації.

Юрій Михайлович Ладуба. - Одеса, 1999. - 20 с. 3. Злепко С. М. Концептуальні основи розробки та впровадження інтегративних технологій управління санаторнокурортними установами / С. М. Злепко, Ю. М. Ладуба // Вимірювальна та обчислювальна техніка в технологічних процесах. - 2000. - №> 4. - С. 152-155. 